\title{
Non-fibrous dust load and smoking in dental technicians: a study using bronchoalveolar lavage
}

\author{
Martine Betnstein, Jean-Claude Pairon, Alfredo Morabia, Annie Gaudichet, \\ Xavier Janson, Patrick Brochard
}

\begin{abstract}
A study was conducted with transmission electron microscopy to find whether bronchoalveolar lavage could be used to identify subjects with occupational exposure to mineral particles. Non-fibrous mineral particles in bronchoalveolar lavage (BAL) fluid from 46 dental technicians and 41 white collar controls with lung diseases but free from occupational exposure to dusts were analysed. The total particle concentration in BAL fluid was significantly higher in dental technicians than in controls $\left(12.18 \times 10^{5}\right.$ particles/ml of BAL fluid, $v 2.03 \times 10^{5}$ particles/ml, p < 0.001). Dental technicians had significantly more crystalline silica, aluminium, and alloys containing nickel and chromium. There was a nonsignificant twofold increase of total particle concentration in the lungs of dental technicians who were smokers compared with non-smokers. The results strongly support the use of BAL fluid analysis to assess dust accumulation in workers in heavily exposed occupations such as dental technicians. This is a valid method to evaluate occupational exposure to nonfibrous mineral particles, and may be useful to determine the occupational aetiology of some respiratory diseases.
\end{abstract}

(Occup Environ Med 1994;51:23-27)

Dental technicians can develop pneumoconiosis with possible progression to respiratory failure in response to inhalation of various occupational dusts. ${ }^{1}$ There is a good correlation between composition of dust particles emanating from grinding and polishing instruments and that deposited in the lung tissue of dental technicians. ${ }^{2}$

Many respiratory diseases result from accumulation of fibrous or non-fibrous mineral particles in the lung. ${ }^{3}$ Analysis of lung samples provides the most direct index for studying the accumulation of mineral dusts in the lung. Lung biopsy or necropsy tissue are rarely available due to the complexities of sampling but bronchoalvealor lavage (BAL) is an easy and non-traumatic procedure that can be used for the analysis of alveolar cytological, immunological, and mineralogical content of the lung. 45

Previous studies have shown that the asbestos body concentration in human BAL fluid is highly correlated with parenchymal concentration. ${ }^{6}$ Characterisation and quantification of asbestos bodies (by optical microscopy) or of fibres (by electron microscopy) in BAL fluid, as well as in lung tissue, can be useful for the diagnosis of interstitial disease, pulmonary malignancy, and mesothelioma. ${ }^{6-8}$ By contrast, few studies have been performed on non-fibrous mineral particles in BAL fluid. ${ }^{9}$ This may be due to the methods required such as transmission electron microscopy or scanning electron microscopy and their associated analytical techniques. Furthermore, non-fibrous mineral fibres are not specific markers (such as asbestos bodies for asbestos). Some are ubiquitous, ${ }^{10}$ which makes it difficult to differentiate non-fibrous mineral fibres associated with occupational exposure from dust commonly inhaled by non-exposed control populations.

Some authors have shown good agreement between the particle types found in BAL fluid and in lung samples of subjects free from recent occupational exposure to non-fibrous mineral particles. ${ }^{10}$ Other authors have described the mineralogical determination of trace elements in alveolar macrophages or BAL fluids of controls ${ }^{11}$ or of exposed workers. ${ }^{12-14}$

Some studies have focused on mineralogical analysis of particles in macrophages or in BAL fluid of pneumoconiotic patients ${ }^{14} 15$ and of subjects with other types of occupational exposure. ${ }^{12-14}$ Only one author has studied the mineralogical lung load of dental technicians. ${ }^{16}$

In our study, analysis of BAL fluid by transmission electron microscopy was performed in dental technicians occupationally exposed to non-fibrous mineral particles and in white collar controls with lung diseases but free from occupational exposure to dusts. The objective was to find whether the analysis of non-fibrous mineral particles in BAL fluid could be used to assess occupational exposures related to respiratory diseases, to determine a reference mineralogical pattern of dusts associated with the occupational exposure of dental technicians, and to assess the influence of smoking on this pattern.

\section{Methods}

STUDY POPULATION

The exposed group consisted of 46 dental technicians for which a mineralogical analysis of non-fibrous mineral particles in BAL fluid was requested between 1981 and 1992. For 
each patient, information on smoking and work history including dates for the beginning and end of each occupation, were recorded on a medical form filled in by physicians. All dental technicians had been in the trade for at least five years. The non-exposed group consisted of 41 patients with respiratory diseases but free of occupational exposure to nonfibrous mineral particles who were recruited during the same period.

\section{BAL FLUID}

The BAL fluid was collected by transnasal fibreoptic bronchoscopy. An initial instillation was performed with $50 \mathrm{ml}$ of sterile saline $(0.9 \% \text { sodium chloride })^{17}$ at $37^{\circ} \mathrm{C}$ that was infused into the right median lobe and then gently aspirated with a syringe. The content of the first aspiration was not used because it collects mostly cells and particles from the large airways. ${ }^{5}$ We only used the two subsequent instillations; $20 \mathrm{ml}$ fluid were taken from aspirates for mineralogical examination.

\section{PARTICLE ANALYSIS}

All chemicals used for preparing the samples were filtered through a Millipore membrane $(0.45 \mu \mathrm{m}$ pore size). Special care was given to all procedures to avoid contamination. The recovered BAL fluid was placed in $10 \mathrm{ml}$ of filtered $10 \%$ formalin and then treated with sodium hypochlorite for two hours at room temperature to digest the organic material. The mixture was then concentrated by filtration through a carbon coated polycarbonate membrane (Nuclepore $0.4 \mu \mathrm{m}$ pore size). After drying for five minutes in an oven, the Nuclepore membrane was again coated with a carbon film and the collected particles were transferred on to copper transmission electron microscope grids as previously described. ${ }^{15}$ The mineralogical analysis was performed with an analytical transmission electron microscope (JEOL $100 \mathrm{C}$ ) equipped with an energy dispersive $x$ ray spectrometer (EDAX 711). For each sample, particles were analysed at magnification $\times 20000$ for morphology and elementary chemical composition in randomly selected fields $\left(24 \mu \mathrm{m}^{2}\right)$. The numerical concentrations of all types of non-fibrous mineral fibres (with diameter $\geqslant 0 \cdot 1 \mu \mathrm{m}) / \mathrm{ml}$ of BAL fluid was first determined by scanning a sufficient number of fields to obtain at least 200 particles. In a second step, relative percentages of different mineralogical species were determined by analysis of 50 to 100 particles in randomly selected fields. Each particle was identified by morphological features, electron diffraction pattern, and microanalysis spectrum.

The composition of elementary particles in the non-fibrous dust load was evaluated. Sixteen different mineralogical species were identified. The silicates measured were crystalline silica, amorphous silica, kaolinite, mica, talc, chlorite, calcite, feldspars, and fly ash. Any other clays found were included as "other silicates". The metallic compounds were aluminium, titanium oxides, alloys, and other metals. "Other metals" included chromium, cobalt, nickel, antimony, bismuth, bromium, cadmium, cerium, copper, gold, lead, magnesium, manganese, molybdenum, palladium, tungsten, zinc, and zirconium. The exogenous and endogenous iron particles were individually determined according to their diffraction pattern and phosphorus content (exogenous showed crystalline features without phosphorus, endogenous were opposite). As the purpose was to study exogenous contaminants, the relative percentages of mineralogical species were calculated, excluding endogenous iron.

\section{STATISTICAL METHODS}

Descriptive statistics including the geometric mean and estimate of SD were reported for each variable. Before calculation, all data were normalised by taking the log and the results were converted back to geometric means with the antilog before being reported in the tables. Mean differences were evaluated with a two sample $t$ test and the F ratio test for variance. Multiple linear regression analysis was used to determine the linear association between variables and to assess potential interaction between smoking, dust exposure, and lung dust load. The calculations were performed with BMDP and SAS statistical software.

\section{Results}

Table 1 shows the sex and smoking history of the 46 dental technicians and 41 controls. The sex ratio was different between controls and exposed subjects with nearly all exposed subjects being men. The average year of birth was 1938 for dental technicians and 1940 for controls.

\section{PARTICULATE LOADING OF THE LUNG}

The mean particulate loading of the lungs of the dental technicians was significantly higher than the controls $\left(12.18 \times 10^{5} v 2.03 \times 10^{5}\right.$ particles $/ \mathrm{ml}$ of BAL fluid; $\mathrm{p}<0.001$; see table 4). No significant difference was found in total particle concentration between male and female controls.

\section{YEARS OF EXPOSURE}

Multiple linear regression gave a statistically significant association between the increase in total particle concentration with the increasing number of years worked as a dental technician (table 2).

Table 1 Characteristics of the 46 dental technicians and 41 controls

\begin{tabular}{lcc}
\hline & $\begin{array}{l}\text { Dental technicians } \\
\text { No (\%) }\end{array}$ & $\begin{array}{c}\text { Controls } \\
\text { No (\%) }\end{array}$ \\
\hline Total & $46(100)$ & $41(100)$ \\
Sex: & & \\
$\quad$ Men & $44(96)$ & $23(56)$ \\
Women & $2(4)$ & $18(44)$ \\
Smokers: & $22(48)$ & $19(46)$ \\
$\quad$ Current & $6(13)$ & $2(5)$ \\
Former & $8(17)$ & $17(42)$ \\
Never & $10(22)$ & $3(7)$ \\
Unknown & & \\
\hline
\end{tabular}


Table 2 Total particle concentration $\left(10^{5} / \mathrm{ml}\right)$ by years of exposure

\begin{tabular}{|c|c|c|c|}
\hline & No & Exposure $(y)$ & Particles $\left(10^{\mathrm{s}} / \mathrm{ml}\right) \dagger$ \\
\hline Controls & 41 & 0 & $2 \cdot 0$ \\
\hline $\begin{array}{l}\text { Dental technicians } \\
(n=39)^{\star}\end{array}$ & $\begin{array}{r}4 \\
8 \\
13 \\
7 \\
4 \\
3\end{array}$ & $\begin{array}{c}1-9 \\
10-19 \\
20-29 \\
30-39 \\
40-49 \\
50-59\end{array}$ & $\begin{array}{l}7 \cdot 4 \\
11 \cdot 9 \\
17 \cdot 5 \\
9 \cdot 7 \\
12 \cdot 2 \\
19 \cdot 7 \\
\text { p Value for } \\
\text { trend }=0 \cdot 0001\end{array}$ \\
\hline
\end{tabular}

*Seven dental technicians had unknown duration of exposure. tGeometric mean.

ELEMENTARY CHEMICAL PARTICLE ANALYSIS Absolute concentrations of crystalline silica, other silicates, exogenous iron, aluminium, metallic alloys, and other metals were significantly higher in the dental technicians than in the controls (table 3 ).

\section{INFLUENCE OF SMOKING}

When dental technicians only were examined, the mean dust value was twice as high in smokers than in non-smokers $\left(14.15 \times 10^{5} v\right.$ $8.14 \times 10^{5}$ particles $/ \mathrm{ml}$ ) but the difference was not statistically significant. In the nonexposed group, smokers and non-smokers had almost the same concentration of particles $\left(2.19 \times 10^{5} v 1.91 \times 10^{5}\right.$ particles $\left./ \mathrm{ml}\right)$ (table 4 ). These results strongly suggest that there is an additive interaction between smoking and dust exposure with respect to dust accumulation but the regression analysis did not show in interaction between smoking history and exposure. In terms of elementary particle analysis, none of the differences between smokers and non-smokers were significant either for dental technicians or for controls (data not presented).

\section{HEALTH EFFECTS}

Medical history of respiratory tract diseases of subjects was taken from their hospital records. Table 5 shows the distribution of lung diseases. Dental technicians had a higher proportion of interstitial lung disease. Silicosis was only found in dental technicians.

\section{Discussion}

This is the first study showing that the mean total particle concentration is significantly higher in dental technicians than in nonexposed controls with lung disease. Chariot et $a l^{10}$ found similar results for absolute particle concentrations in BAL fluid of 10 necropsy cases and the statistically significant correlation of total particle concentration with duration of exposure to non-fibrous mineral particles strongly supports results found in dental technicians.

In terms of chemical content, the relative and absolute concentrations in BAL fluid showed several differences between dental technicians and controls. Crystalline silica, exogenous iron, aluminium, metallic alloys, and other metals (including chromium and cobalt) were significantly increased in the BAL fluid of dental technicians both in relative percentages and in absolute concentrations.

An increase of a given mineral as a possible result of occupational exposure automatically reduces the relative percentages of other minerals. Thus only increases in the absolute concentration of the mineralogical species in dental technicians compared with controls were considered pertinent in terms of pulmonary dust load.

Attempts to characterise mineralogical species in BAL fluid from dental technicians have been rare, in particular, to provide absolute concentrations of particles and their populations. Also, previous reports used different techniques making comparison difficult. The combination of silica, aluminium, chromium, and cobalt has been identified in the dusts emanating from grinding and polishing instruments used by dental technicians. ${ }^{218}$ This is in agreement with our results in which crystalline silica, aluminium, alloys and other metals (including chromium and cobalt) were significantly increased. ${ }^{2} 16$

The use of a transmission electron microscope fitted with an energy dispersive $x$ ray analysis system to study individual particles provides a better spatial resolution than the scanning electron microscope. One study performed on 30 lung preparations also used the transmission electron microscope but

Table 3 Elementary particle concentration $\left(10^{3} / \mathrm{ml}\right)$ in dental technicians and in controls

\begin{tabular}{|c|c|c|c|c|c|}
\hline \multirow[b]{3}{*}{ Components } & \multicolumn{4}{|c|}{ Particles $\left(10^{3} / \mathrm{ml}\right)$} & \multirow[b]{3}{*}{$p$ Value } \\
\hline & \multicolumn{2}{|c|}{ Dental technicians } & \multicolumn{2}{|c|}{ Controls } & \\
\hline & No & $\operatorname{Mean}^{*}(S D)$ & No & $\operatorname{Mean}^{\star}(S D)$ & \\
\hline Crystalline silica & 46 & $553.6(11694.8)$ & 41 & $56 \cdot 8(380 \cdot 6)$ & 0.0000 \\
\hline Amorphous silica & 46 & $38.7(257 \cdot 1)$ & 41 & $10 \cdot 7(9 \cdot 2)$ & NS \\
\hline Kaolinite & 46 & $45 \cdot 6(213.2)$ & 41 & $40 \cdot 1(132 \cdot 0)$ & NS \\
\hline Mica & 46 & $29.6(128 \cdot 8)$ & 41 & $40.6(246.4)$ & NS \\
\hline Talc & 46 & $15 \cdot 7(35 \cdot 1)$ & 41 & $5.4(6.9)$ & NS \\
\hline Chlorite & 46 & $1 \cdot 2(1 \cdot 0)$ & 41 & $2.9(0.8)$ & NS \\
\hline Other phyllosilicates & 46 & $8.8(20.9)$ & 41 & $1.6(0.6)$ & NS \\
\hline Feldspars & 46 & $81 \cdot 7(771 \cdot 1)$ & 41 & $39 \cdot 3(473 \cdot 3)$ & NS \\
\hline Other silicates & 46 & $71 \cdot 1(446 \cdot 8)$ & 41 & $11.6(9 \cdot 0)$ & 0.0002 \\
\hline Calcite & 46 & $26.4(73.9)$ & 41 & $17.5(23.3)$ & NS \\
\hline Exogenous iron & 46 & $76 \cdot 5(750 \cdot 6)$ & 41 & $10.9(11.9)$ & 0.0057 \\
\hline Aluminium & 46 & $182 \cdot 7(3703 \cdot 5)$ & 41 & $4.9(3.8)$ & 0.0000 \\
\hline Titanium & 46 & $12 \cdot 2(18 \cdot 9)$ & 41 & $12(11 \cdot 1)$ & NS \\
\hline Metallic alloys & 46 & $123.9(908.3)$ & 41 & $20 \cdot 2(90 \cdot 8)$ & 0.0000 \\
\hline Other metals & 46 & $21 \cdot 3(48 \cdot 2)$ & 41 & $2.9(0.9)$ & 0.0016 \\
\hline Fly ash & 46 & $0.4(0.1)$ & 41 & $6 \cdot 0(7 \cdot 4)$ & NS \\
\hline
\end{tabular}

${ }^{\star}$ Geometric mean; tp Value for unpaired $t$ test for unequal variance; SD $=$ geometric mean $\times$ SD (ln data). 
Table 4 Total particle concentration $\left(10^{5} / \mathrm{ml}\right)$ by exposure and smoking

\begin{tabular}{lrllll}
\hline Smoking history & No & Mean $^{*}(S D)$ & Min & Max & $p$ Value \\
\hline Controls: & & & & & \\
$\quad$ Non-smokers & 17 & $1.91(8.65)$ & 0.1 & 71.0 & NS \\
$\quad$ Smokers & 21 & $2.19(4.23)$ & 0.76 & 14.6 & NS \\
$\quad$ Unknown & 3 & & & & \\
$\quad$ All & 41 & $2.03(5.89)$ & 0.1 & 71.0 & $<0.0001$ \\
$\begin{array}{l}\text { Dental } \\
\text { technicians: }\end{array}$ & & & & & \\
$\quad$ Non-smokers & 8 & $8.14(34.19)$ & 0.8 & 94.0 & NS \\
$\quad \begin{array}{l}\text { Smokers } \\
\quad \text { Unknown }\end{array}$ & 10 & $14.15(38.21)$ & 1.7 & 150.0 & NS \\
$\quad$ All & 46 & $12.18(34.10)$ & 0.8 & 150.0 & $<0.0001$ \\
\hline
\end{tabular}

${ }^{\star}$ Geometric mean; SD as table 3.

$\mathrm{SD}$, estimate of the $\mathrm{SD}=$ geometric mean $\times \mathrm{SD}$ (ln data)

expressed results in terms of positive mineralogical species in alveolar macrophages. ${ }^{2}$ This study did not provide details about the duration of the exposure, but the results showed an increase in aluminium and silica in all cases. Similar results were found in the lung tissue of five French dental technicians by the Castaing's sensor. ${ }^{19}$ De Vuyst et al also used that method with two dental technicians, but they did not provide absolute concentrations. ${ }^{16}$

Aside from these studies, few authors have used transmission electron microscopes fitted with an energy dispersive $x$ ray analysis system to study individual particles in BAL fluid. ${ }^{14}$ One author expressed results from transmission electron microscopy in terms of positive mineralogical species in alveolar macrophages. ${ }^{2}$ Others measured trace elements in alveolar cells with an energy dispersive $x$ ray fluorescence method and expressed results in ponderal concentration per $10^{3}$ cells. ${ }^{15} 15$ Some authors used a scanning electron microscope fitted with $x$ ray spectrometry and polarised light microscopy to determine the mineralogical load in alveolar macrophages. ${ }^{13}$ These methodological discrepancies preclude direct comparison even for the results in the control groups.

Other factors may influence the results of mineralogical analysis of the particles recovered from BAL fluid and thus comparability of data from different studies.

Preparation of the BAL fluid samples may greatly influence subsequent mineralogical analysis, especially when fragmentation of

Table 5 Pathology in dental technicians and controls

\begin{tabular}{lcc}
\hline Pathology & $\begin{array}{l}\text { Dental technicians } \\
\text { No (\%) }\end{array}$ & $\begin{array}{l}\text { Controls } \\
\text { No (\%) }\end{array}$ \\
\hline Interstitial lung disease & $34(74)$ & $4(10)$ \\
Definite silicosis & $6(13)$ & $0(0)$ \\
Mesothelioma & $1(2)$ & $0(0)$ \\
Chronic destructive & $3(7)$ & $7(17)$ \\
$\quad$ lung disease & $1(2)$ & $0(0)$ \\
Pneumothorax & $1(2)$ & $6(15)$ \\
Lung cancer & $0(0)$ & $10(24)$ \\
Sarcoidosis & $0(0)$ & $4(10)$ \\
Lung infection & $0(0)$ & $3(7)$ \\
Tuberculosis & $0(0)$ & $2(5)$ \\
Adenopathy & $0(0)$ & $1(2)$ \\
Haemoptisy & $0(0)$ & $4(10)$ \\
Unknown & & \\
\hline
\end{tabular}

*Lung disease with increase or profusion of small $x$ ray film opacities conglomerates occurs in highly concentrated samples. Reviews on methodological pitfalls linked to specimen preparation of BAL fluid or lung tissue have been published for scanning electron microscopy and polarised light microscopy, ${ }^{20}$ and for comparison of scanning and transmission electron microscopy methods in lung tissue. ${ }^{21}$ The technique used in our study avoided any centrifugation or sonication of the BAL fluid samples. Also, incomplete solubilisation or organic digestion of the sample may lead to erroneous results. Sodium hypochlorite is considered an effective tissue digestant and does not seem to react with natural mineral dusts. ${ }^{17}$

The size of the particles taken into account for mineralogical analysis could also create an important difference between results: whereas some authors using transmission electron microscopes count all particles greater than $0 \cdot 1 \mu \mathrm{m},{ }^{1420}$ others gave results for particles greater than $1 \mu \mathrm{m}$ as polarised light microscopy did not allow detection of smaller particles.

There were no significant differences in mineralogical analysis among male and female controls in our study and the number of female dental technicians was too small to allow any specific analysis. Our search of published reports has produced no study designed to assess sex differences in the BAL fluid dust load.

Cigarette smoking is toxic for the ciliated epithelial lining of the respiratory tract, ${ }^{22}$ possibly decreasing the clearance mechanism for particulates. Tobacco has also been shown to contain various mineral particles such as crystalline silica, feldspars, iron and titanium oxide particles, and phyllosilicates. ${ }^{22}$ Few studies have focused on the influence of smoking on the mineralogical content of BAL fluid. Christman et al did not find any significant effect of smoking on the mineral content of alveolar macrophages. ${ }^{13}$ Some authors found a significant effect of smoking on total non-fibrous mineral particle retention and relative mineral species found in human lungs, ${ }^{23}$ whereas others did not. ${ }^{24}$ Churg and Wiggs noted that the effect of smoking was limited to the upper lobes, a region usually not sampled by BAL. ${ }^{23}$

We found no effect of smoking on total particle concentrations in BAL fluid of controls and dental technicians. In dental technicians, smokers had higher particle concentrations but the difference was not statistically significant. Because the statistical power of the study was too small to show an interaction between occupational exposure, smoking, and dust concentration, however, larger studies are warranted before any conclusion can be made.

All dental technicians and controls were patients with respiratory diseases for which a mineralogical analysis of non-fibrous mineral particles in BAL fluid was requested. Interstitial lung disease and silicosis were found more frequently in dental technicians than in controls. This is not surprising as lung interstitial disease and silicosis have already 
been reported in dental technicians and associated with exposure to crystalline silica and metallic particulates. ${ }^{216} 18$

In summary, for the first time, work as a dental technician has been linked with an increase in concentration of non-fibrous mineral particles in BAL fluid. These results have a practical implication: the measure of nonfibrous mineral particles in BAL fluid could be used to evaluate occupational exposure in dental technicians. A further step should be to study the association of BAL fluid dust concentration with the risk of developing a lung disease. The BAL fluid procedure in conjunction with energy dispersive $x$ ray microanalysis could then be a useful tool for the aetiological diagnosis of interstitial lung disease. Standardisation in BAL fluid sampling and mineralogical analysis will allow guidelines to be created about the significance of particle concentrations in BAL fluid in terms of risk of lung disease. ${ }^{25}$

We are very grateful to Marie-Annick Billon-Galland and Brigitte Couste (Laboratoire d'Etude des Particules Inhalées, Paris) who worked on the BAL fluid analysis and to the colleagues who's patients have been included in this study. We also thank Professor Alan Ross for his critical comments about statistical analysis.

1 Rom WN, Lockey JE, Lee JS, Kimball AC, Bang KM Leaman $\mathrm{H}$, et al. Pneumoconiosis and exposures of dental laboratory technicians. Am $\mathcal{f}$ Public Health 1984;74:1252-7.

2 Morgenroth K, Kronenberger H, Michalke G, Schnabel R. Morphology and pathogenesis of pneumoconiosis in dental technicians. Pathol Res Pract 1985;179:528-36.

3 Parkes W R. Occupational lung disorders. 2nd ed. London: Butterworths, 1982

4 Daniele RP, Elias JA, Epstein PE, Rossman MD. Bronchoalveolar lavage: role in the pathogenesis, diagnosis and management of interstitial lung disease. Ann Intern Med 1985;102:93-108.

5 The BAL Cooperative Group Steering Committee. Bronchoalveolar lavage constituents in healthy individuals, idiopathic pulmonary fibrosis and selected compan

6 Sebastien P, Armstrong B, Monchaux G, Bignon J. Asbestos bodies in bronchoalveolar lavage fluid and in lung parenchyma. Am Rev Respir Dis 1988;137:75-8.

7 Gaudichet A, Sebastien P, Bient M, Jaurand MC, Atassi K, Bonnaud G, Bignon J. Métrologie des fibres d'amiante recueillies par lavage bronchoalvéolaire. Revue $M a$ Respir 1978;6:345-51.
8 Sebastien P. Possibilités actuelles de la biométrologie des poussières sur échantillon de liquide de lavage bronchoalvéolaire. Ann Biol Clin (Paris) 1982;40:270-93.

9 Gaudichet A, Pairon JC, Malandain O, Couste B, Brochard P, Bignon J. Etude minéralogique des particules non fibreuses du liquide de lavage bronchoalvéolaire. Revue Mal Resp 1987;4:237-43.

10 Chariot P, Couste B, Guillon F, Gaudichet A, Bignon I, Brochard P. Nonfibrous mineral particles in bronchoalveolar lavage fluid and lung parenchym from the general population. Am Rev Respir Dis 1992;146:61-5.

11 Maier E A, Rastegar F, Heimburger R, Ruch C, Pelletier A, Maier A, Leroy MJF. Simultaneous determination of A, Maier A, Leroy MJF. Simultaneous determination of trace elements in lavage fluids from human bronchial
alveoli by energy dispersive $\mathrm{x}$-ray fluorescence. 1alveoli by energy dispersive $x$-ray fluorescence. 1-
Technique and determination of the normal reference Technique and determination of the

12 Corhay JL, Delavignette JP, Bury Th, Roelandts I, Weber $\mathrm{G}$, Radermecker MF. Analyse minéralogique du liquide de lavage bronchoalvéolaire de sidérurgistes. Archives des Maladies Professionelles 1991;52:339-44.

13 Christman JW, Emerson RJ, Hemenway DR, Graham WGB, Davis G S. Effects of work exposure retirement, and smoking on bronchoalveolar lavage measurements of lung dust in Vermont granite workers. Am Rev Respir Dis 1991;144:1307-13.

14 De Vuyst $P$, Dumortier P, Leophonte $P$, Vande Weyer $R$ Yernault JC. Mineralogical analysis of bronchoalveolar lavage in talc pneumoconiosis. Eur $\mathcal{f}$ Respir Dis 1987 ; lavage in

15 Johnson NF, Haslam PL, Dewar A, Newman-Taylor AJ Turner-Warwick $M$. Identification of inorganic dust particles in bronchoalveolar lavage macrophages by energy dispersive X-ray microanalysis. Arch Environ Health 1986;41:133-44.

16 De Vuyst $P$, Vande Weyer R, De Coster A, Marchandise F X, Dumortier P, Ketelbaut P, et al. Dental technician's pneumoconiosis. A report of two cases. $A m \operatorname{Rev}$ Respir Dis 1986;133:316-20.

17 Liebling R S, Hatt T. Extraction of mineral dusts from lung tissue using sodium hypochlorite. Environ Lett $1971 ; 2: 153-65$.

18 Peltier A, Moulut JC, Demange M. Le risque de pneumoconiose chez les technicians dentistes. INRS publication coniose chez les tech

19 Carles P, Fabre J, Pujol M, Duprez A, Bollinelli R Pneumoconioses complexes chez les prothésistes dentaires. Archives des Maladies Professionelles 1978;3 189-92.

20 Abraham JL. Documentation of environmental particulate exposures in humans using SEM and EDXA. Scanning Electron Microscopy 1979;2:751-66.

21 Chatfield EJ, Dillon MJ. Some aspects of specimen preparation and limitations of precision in particulate analysis by SEM and TEM. Scanning Electron Microscopy 1978; 1:487-96.

22 The health consequences of smoking. Cancer and chronic lung disease in the workplace. A report of the Surgeon General (1985). Washington DC: US Government printing office: 1987, 189-339.

23 Churg A, Wiggs B. Types numbers, sizes and distribution of mineral particles in the lungs of urban male cigarette smokers. Environ Res 1987;42:121-9.

24 Stettler LE, Platek SF, Riley RD, Mastin JP, Simon SD Lung particulate burdens of subjects from the Cincinnati, Ohio urban area. Scanning Microsc 1991; 5:85-94.

25 Costabel U, Donner CF, Haslam PL, Rizzato G, Teschler $H$, Velluti G, Wallaert B. Clinical role of BAL in occupational lung diseases due to mineral dust exposure. Eur Respir f 1992;2:89-96.

\section{Destruction of manuscripts}

From 1 July 1985 articles submitted for publication will not be returned. Authors whose papers are rejected will be advised of the decision and the manuscripts will be kept under security for three months to deal with any inquiries and then destroyed. 